Hydrol. Earth Syst. Sci. Discuss., https://doi.org/10.5194/hess-2017-755

\title{
Reduction Assessment of Agricultural Non-Point Source Pollutant
}

\section{Loading}

1. State Key Laboratory of Simulation and Regulation of River Basin Water Cycle, China Institute of Water Resources and Hydropower Research, Beijing, 100038, China

7 2. Yellow River Conservancy Technical Institute, Kaifeng Henan, 475004, P.R. China

$8 \quad *$ Corresponding author, E-mail: swfyc@ 126.com

9 Abstract:

10 NPS (Non-point source) pollution has become a key impact element to watershed environment at present.

11 With the development of technology, application of models to control NPS pollution has become a very 12 common practice for resource management and Pollutant reduction control in the watershed scale of China.

13 The SWAT (Soil and Water Assessment Tool) model is a semi-conceptual model, which was put forward to 14 estimate pollutant production \& the influences on water quantity-quality under different land development 15 patterns in complex watersheds. Based on the overview of published papers with application of SWAT, the 16 study topics is mainly focus on nutrients, sediments, impoundment \& wetlands, hydrologic characteristics, 17 climate change impact, and land-use change impacts. SWAT model was constructed based on rainfall runoff and land use type. The migration-transformation processes of agricultural NPS pollution was simulated and

19 calculated based on the SWAT model. Besides, the loadings and distribution traits of NPS pollutants were 20 also systematically analyzed based on the model. The model was used to quantify the spatial loading 21 intensities of NPS nutrient TN (Total Nitrogen) and TP (Total Phosphorus) to HTRW (Huntai River 22 Watershed) under two scenarios (without \& with buffer zones). The SWAT model was validated using actual 23 monitoring information as well as the physical properties of the underlying substrate, hydrology, 24 meteorology and pollutant sources in the HTRW. Scenario settings are mainly based on the changes of 25 surface runoff and sediments, climate and land-use change from different spatial scales, and climatic/ 
Hydrol. Earth Syst. Sci. Discuss., https://doi.org/10.5194/hess-2017-755

physiographic zones. About $1 \mathrm{~km}$ within both banks of the trunk streams of the Huntai, Taizi and Daliao rivers, and $5 \mathrm{~km}$ surrounding the reservoirs were defined as buffer zones. Existing land use type within the buffer zone was changed to reflect the natural environment. The output of pollutant production under the EPS (Environmental Protection Scenarios) was calculated based on the status quo scenario. Under the status quo scenario, the annual mean modulus of soil erosion in the HTRW was $811 \mathrm{~kg} / \mathrm{ha}$, and the output intensities of TN \& TP were $19 \& 7 \mathrm{~kg} / \mathrm{ha}$, respectively. For the unit area, the maximal loading intensities for TN \& TP were $365.36 \& 259.83 \mathrm{~kg} / \mathrm{ha}$, respectively. In terms of spatial distribution, TN \& TP loading varied substantially. Under the EPS, the magnitude of $\mathrm{N} \& \mathrm{P}$ production from arable land decreased to a certain degree, and the TN \& TP pollution loading per unit area were reduced by $5 \& 1 \mathrm{~kg} / \mathrm{ha}$ annually, respectively. In comparison, the quantity of NPS pollutant production under the EPS was reduced by $21.9 \%$ compared with the status quo scenario, and the quantities of TP \& TN decreased by $10.4 \% \& 25.9 \%$, respectively. These changes suggested a clear reduction in the export loading of agricultural NPS pollution. Loading intensities analysis showed that land use type is one key factor for controlling NPS pollution. The NPS pollutant loading decreased under the EPS, which showed that environmental protection measure could effectively cut down NPS pollutant loading in HTRW. SWAT was used to assess the reduction of agricultural NPS pollutant. However, SWAT model requires a large amount of data about the watershed being modeled; the data inaccuracy and local factors would impact the accuracy of the SWAT model. To determine the pollutant reduction under different land development patterns, and examine uncertainty of sensitivity parameters, SWAT model in China has wide range of potential application.

\section{Key words:}

agricultural NPS pollutant loading; Huntai River Watershed; status quo scenario; environmental protection scenarios

\section{Introduction}

NPS pollution has become key influencing factor to improve surface water quality. There are many literatures have illustrated that underlying surface condition \& precipitation characteristics will impact the 
Hydrol. Earth Syst. Sci. Discuss., https://doi.org/10.5194/hess-2017-755

spatial distribution characteristics of NPS pollution nutrient loading (Robinson et al.,2005; Lindenschmidt et al.,2007). The pollutant production from different land use types vary substantially (Niraula et al.,2013). The concentrate on NPS pollution is dependent on discharge it is highly variable and does not enable a fair comparison between different areas (Tucci 1998; Dingman 2002; de Oliveira et al.,2016). Loadings are considered better for comparing watersheds and for establishing the relationship between pollutants and land use (Quilb'e et al.,2006). At present, many researchers have preferred loadings over concentrations to convey their research (Yang et al., 2007; Ouyan et al.,2010; Outram et al., 2016). Land use types \& underlying surface condition will influence the resources and nutrients distribution, and which will result in the reduction of NPS pollutant loading (Hundecha et al.,2004; Ahearn et al., 2005; Ouyang et al., 2013). In general, the spatial-temporal characteristic of NPS pollutant can be studied based on data statistics \& model simulation (Shen et al.,2013a). SWAT model can be determined NPS pollutant loading \& supplied the decision-making program for watershed comprehensive development (Shen et al.,2011). Many documents have confirmed the combination of different land development patterns \& landscape characteristics could reduce NPS pollution (Seppelt et al., 2002; Sadeghi et al.,2009).

Distributed physics \& semi-conceptual models are effective means to calculate and assess the NPS pollution spatial loading intensities. At the end of the $20^{\text {th }}$ century, the SWAT model was developed by American scientists of USDA-ARS (Arnold et al.,1998). SWAT has been widely used in runoff simulation, the calculation of NPS pollution \& implementation of best management practices. The SWAT was widely used in assessing the impact of NPS pollution under different land use types, for which was consisted by underlying surface, vegetation coverage, hydrometeorology, and agricultural production modules. The production changes of agricultural NPS nutrients based on diverse land development patterns have been studied \& analyzed by SWAT model (Ficklin et al.,2009; Shen et al., 2013b; Geng et al., 2015). The main body of SWAT model includes 701mathematical equations \& 1013 intermediate variables, which has been widely used to calculate \& assess the distribution traits of NPS pollutant loading, as well as analyze the effects of land use and its spatiotemporal distribution pattern on NPS pollutant \& soil loss in watershed scale (Mapfumo et al.,2004; Gosain et al.,2005; Ouyang et al., 2009; Logsdon et al.,2013). 
Hydrol. Earth Syst. Sci. Discuss., https://doi.org/10.5194/hess-2017-755

The HTRW is the important tributary of Liaohe River Basin, which has been polluted seriously in recent years. The main NPS pollution in Liaohe River is agricultural NPS pollution, and most NPS pollution happens in HTRW within Liaoning province (Liaoning Province DEP, 2011). Therefore, the HTRW face immense pressure due to water pollution. According to the twelfth five-year developmental plan, the annual mean growth of GDP in the Liaohe River watershed was greater than $13 \%$ and the urbanization rate was close to $75 \%$. The policy of 'Revitalization of Old Industrial Bases in Northeast China' has caused significant changes in the land-use structure (Liu et al.,2014). This accelerating urbanization alters the existing land use type in a way that results in more NPS pollution to local surface waters (Kuai et al.,2015). HTRW is the Basic product manufacturing base in China.

The SWAT of the present study was used to quantify the spatial loading intensities of TN \& TP to HTRW under different land use types, and assess the adaptability changes based on NPS pollutant loading reduction. Nutrient losses were simulated in different scenarios-status quo scenario (without buffer zones) and "environmental protection" scenario (EPS, with buffer zones), using SWAT. The flow chart of this study was to: (1) elaborate the underlying surface (land use) changes in the HTRW; (2) simulate the NPS pollution loading (TP \& TN) of the HTRW under two scenarios; (3) contrast the different of NPS pollution loading in two scenarios, and assess the effect of reducing pollution loading under EPS. In this paper, the SWAT was used to estimate the agricultural NPS pollution loading of HTRW, and digital comparison analysis method was utilized to analyze the spatial distribution characteristics of pollution loading.

\section{Materials \& methods}

\subsection{HTRW}

The HTRW $\left(40^{\circ} 27^{\prime} \sim 42^{\circ} 19^{\prime} \mathrm{N}, 121^{\circ} 57^{\prime} \sim 125^{\circ} 20^{\prime} \mathrm{E}\right)$ is in Liaoning province (Northeast China), and the watershed area is $2.73 \times 10^{4} \mathrm{~km}^{2}$, which takes about $1 / 5$ of the area of Liaoning province (Fig 1). The HTRW is a tributary of Liaohe River Basin (The Liaohe River Basin is one of China's larger water systems) and is consist of Hunhe River, Taizi River, and Daliao River. The Hunhe River, Taizi River, and Daliao River watershed is HTRW's subwatershed. The HTRW has varied topography, low mountain is located in eastern part, and the other parts are 
Hydrol. Earth Syst. Sci. Discuss., https://doi.org/10.5194/hess-2017-755

alluvial plain. The elevation of northeast region is high. Loamy soils are mainly distributed in alluvial plain, and the average grade of lower HTRW is about 7\%. HTRW area includes the cities of Fushun, Shenyang, Benxi, Liaoyang, Anshan, and Yingkou, most of Panjin city, some portions of Tieling city and a minor portion of Dandong city. The maxim runoff in the watershed is $76.32 \times 10^{8} \mathrm{~m}^{3}$, primarily concentrated in June through September. The stream flow and nutrient were validated based on the five monitoring stations, Beikouqian, Dongling Bridge and Xingjiawopeng are located in Hunhe River, Xialinzi and Tangmazhai are in Taizi Rive. The total population of HTRW is 18.9 million people. The GDP is about $62 \%$ of Liaoning Province in 2012. HTRW has temperate continental climate, the average annual temperature is $7^{\circ} \mathrm{C}$, and precipitation is $748 \mathrm{~mm}$.

The HTRW is in a conventional agricultural farming area, with a large area of farmland dominated by crop plants. The total area of farmland is $10763 \mathrm{~km}^{2}$ (account for $39.4 \%$ of the total area), including $4086 \mathrm{~km}^{2}$ of paddy field (dominated by rice) and $6677 \mathrm{~km}^{2}$ of dry farmland (including corn, soybean, vegetables and other crop plants). The upper reaches of the Hunhe and Taizi rivers have mountainous (69\%), low hilly $(6.1 \%)$ and plain land (24.9\%). The economic output value of HTRW is dominated by agriculture. The farmland is mainly distributed in the floodplain area and valleys in riverine belts. Considering land pattern, rainfall and source of pollutants, the HTRW faces a high risk of pollution from agriculture. Heavy use of fertilizers and soil erosion in the upper of HTRW has led to serious NPS pollution in HTRW. For example, the Dahuofang reservoir of the Hunhe River and the water resources conservation area in its upper reaches are facing multiple threats, the agricultural NPS pollution is becoming increasingly serious and has not yet been controlled effectively (Shen et al., 2013c).

Fertilization in the HTRW is predominantly with nitrogen, followed by phosphorous and potassium. The heavy use of chemical fertilizers was mainly urea, diammonium phosphate and a small amount of potassium phosphate compound fertilizer. Atrazine and acetochlor were mainly used on dry farmland, and butachlor was mainly used in paddy fields. Based on the statistical data for 2006-2012, the quantity of fertilizers and pesticides applied in the watershed fluctuated annually. The upper reaches of the Huntai and Taizi rivers are dominated by mountains, the cultivation and harvesting of crops are conducted by hand, and therefore thorough statistics are not available. At present, weeds and pests in farmlands were mainly controlled by 
Hydrol. Earth Syst. Sci. Discuss., https://doi.org/10.5194/hess-2017-755

pesticides and herbicides. The upstream is rich in forest resources, the downstream has a large number of farmland, special landscape layout makes the HTRW become potential area for agricultural NPS pollution.

\subsection{Model description}

\subsubsection{SWAT principle}

SWAT is a semi-physical model developed to quantitatively calculate the response status of water quantity \& quality to land use and management methods in the scale of watershed (Gassman et al.,2007). SWAT is an effective to determine the long-term impact using monitoring data (Arnold et al.,2012). The basic data input for model running includes DEM (Digital Elevation Model)/topography, soil type, vegetation status/Land landscape, and BMPs (Best Management Practices scenarios). The calculation unit of watershed SWAT model is sub-watershed, and HRU (Hydrological Response Units), the unit delineation is based on the underlying surface status, vegetation coverage, soil classification, and land use (Neitsch, 2005).

The HRUs of SWAT are automatically divided according to soil conditions, DEM, geomorphological features, and land development (Douglas-Mankin et al., 2010). For the calculation process is realized on HRU, therefore, we selected $0 \%$ land development, elevation/slope, and soil classification/attributes as the initial value in the scale of HTRW, therefore, 184 HRUs were delineated to determine NPS pollutant loading. In order to assess pollutant loss and ecological flow status, the flow curve, soil nutrient loss curve, and water-salt balance equation were applied during the period of model debugging. Meteorology data (sun radiation, atmospheric pressure, atmospheric temperature, precipitation and wind speed) were obtained from meteorological and hydrological stations of 12 cities located within HTRW. The data of BMPs, such as crop sowing/harvest time, crop irrigation time, cultivation structure of cultivated land, fertilizer-use efficiency, and farmland planting plan were got from agriculture \& environmental management department, or collected from the survey of farmers status quo. Based on the above assessment results, we used QUAL2E (water quality model) to determine N \& P yields loading, the route of sediment transport, and pollutant concentration of watershed outlet. 
Hydrol. Earth Syst. Sci. Discuss., https://doi.org/10.5194/hess-2017-755 processes occur simultaneously with the processes of the hydrological cycle and soil erosion. The $\mathrm{N} \& \mathrm{P}$ cycles simulation of SWAT was developed based on 5 different forms of $\mathrm{N}$ and 6 different forms of $\mathrm{P}$, respectively. The $\mathrm{N} \& \mathrm{P}$ cycles were consisted of the process of decomposition, mineralization, fixation, and conversion. The NPS pollutant loading function is the basis of assessing $\mathrm{N} \& \mathrm{P}$ transport and transformation (McElroy, 1976; Williams et al.,1978; Zhang, 2005). Organic N \& P losses calculation of SWAT was achieved by the integrated function of soil nutrient curve, NPS pollutant loading, soil properties change rate, and crop growth characteristics. The total amount of nitrate in lost soil was calculated by the product of water volume and nitrate concentration in water. Water volume is the consisted of surface runoff, groundwater runoff, and interflow/subsurface flow. The soluble P removed in runoff is estimated using the $\mathrm{P}$ concentration in the top soil layer, runoff volume and the $\mathrm{P}$ soil partitioning coefficient. The concentration of soluble $\mathrm{P}$ in water is calculated by topsoil $\mathrm{P}$ stocks, runoff variation, ratio of soluble $\mathrm{P}$, and soil particle characteristics.

Surface runoff from daily precipitation in HRU/Sub-watershed was calculated \& assessed using the SCSCN corresponding relationship curve and rainfall-runoff Coefficient (USDA Soil Conservation Service. National Engineering Handbook, 1972). With SCS-CN curve, saturated moisture, soil water profile/vertical distribution of soil moisture content, runoff module number of the underground water is determined, as well as the related parameters daily of precipitation. The total discharge of runoff from sub-watershed/ HRUs is the sum of surface runoff flow, groundwater runoff flow, and interflow/subsurface flow. Domestic water \& irrigation water is direct consumptive water resources, the mainly water resources is surface runoff $\&$ groundwater runoff (Neitsch,2005). The main routing of water circulation in SWAT is network-node diagram and natural-artificial dualistic water cycle mode. In the paper, we used a dualistic method for multilayer and multi-function separation and interception of the rainfall and run off resources. Circulating flow of SWAT was varied with the dynamic changes of evaporation, infiltration, transport, and return flow (Arnold et al.,1998). The HRUs of SWAT used soil erosion modulus, soil \& water loss coefficient, and Universal Soil Loss Equation (MUSLE) to analyze erosion and sediment yield (Williams, 1975). Sediment 
Hydrol. Earth Syst. Sci. Discuss., https://doi.org/10.5194/hess-2017-755

is routed through channels using Bagnold's sediment transport equation (Bagnold, 1977). We used 2009 version of SWAT to calculate the correlation parameters.

\subsubsection{Model data input}

The data of DEM, geomorphology, underlying surface status, soil properties, land cover, meteorological \& hydrological data (precipitation, evaporation, temperature, and atmospheric pressure, et al.) were input to achieve the operation of SWAT (Niraula et al.,2013). Figure 2 supplied the basic data information to be used in SWAT model. We used $30 \times 30$ grid data (elevation) as the basis for DEM operation. The DEM was selected as the topographical basis on which to construct the SWAT model, to extract the scope of the study area and to construct the topographical model. The stream network in the study area was extracted using 1:250 000 digital water system data (data source: www.geodata.com) as an ancillary model to construct the stream network model of the HTRW. We classified land use types into 27 categories. The main type of land use of HTRW is forest (including orchard, 48.64\%), dry land (24.38\%), rice paddy (14.92\%), urban land (vacant land, 7.78\%) and unused land (uncultivated land, 1.85\%) grassland (0.92\%). Soil types were categorized into 26 types, the primary soil types in this area are brown soil (54.1\%), meadow soil $(29.7 \%)$ and paddy soil $(11.0 \%)$. The database of the underlying substrate was constructed based on the database of soil types using the soil properties \& land development data as underlying substrate parameters (Liu et al.,2015). The soil parameters were obtained from National earth system science data sharing infrastructure database. The watershed meteorological data (precipitation, evaporation, and temperature) used in the present study include precipitation data for 1990-2009 collected by 76 rainfall stations and air temperature data for1990-2009 collected by 12 city meteorological stations. We used meteorological monitoring data for the simulation of precipitation \& evaporation. The missing meteorological information (rainfall, humidity $\&$ atmospheric pressure, air temperature, solar radiation $\&$ wind speed data) can be generated using the weather data generator simulation. At least 3 sets monthly monitoring data of nitrate $\left(\mathrm{NO}_{3}\right)$, nitrite $\left(\mathrm{NO}_{2}\right)$, Ammonia $\left(\mathrm{NH}_{3}, \mathrm{NH}\right)$, $\mathrm{TP}$, and $\mathrm{TP}$, were available in the time of 2006-2009. We got the information of crop type, farming system, sowing time, fertilization time, and social economics from investigation and statistics department in HTRW. All the data were validated 
Hydrol. Earth Syst. Sci. Discuss., https://doi.org/10.5194/hess-2017-755

by the standard procedures used by the SWAT.

The data information (type, scale, description, and source) of SWAT in HTRW are showed in Figure 2. We input the related meteorological and soil data of SWAT got from China Meteorological Administration and Environmental-Ecological Science Data Center for West China. The China Hydrology, water resources \& water quality monitoring department of HTRW provided the automatic \& regular monitoring hydrological data. The Liaoning province Water Resources Administrative Bureau granted permission for the modelling of the pollutant production response to different land utilization scenarios in the HTRW.

\subsubsection{Calibration and validation}

The data of monthly scale were used to achieve the simulation of SWAT. We used the code open SWATCUP module to calibrate parameters of SWAT in HTRW automatically (Abbaspour et al.,2007). Sequential uncertainty fitting algorithm has higher calculation accuracy and simple application method, which was extensive used in the SWAT-CUP module (Wang et al.,2014; Yang et al.,2008). The $E_{N S}$ can effectively avoid the uncertainty of hydrological sequence (precipitation, water flow, and evaporation), which was used to evaluate the run-off flow change of hydrological station in HTRW (Nash, 1970).

The model for the present study was calibrated and tested using artificial parameter modification and automatic calibration. First, the runoff was calibrated, followed by N, P and other nutrients. The runoff was calibrated and tested using real data from the Xingjiawopeng, and Tangmazai hydrological station (Figure 4). The simulated values of $\mathrm{N}$ and $\mathrm{P}$ were calibrated using monitoring data from Beikouqian, Dongling bridge, Xingjiawopeng, Xiaolinzi, and Tangmazhai hydrological station. Various hydrologic and water quality parameters were adjusted under their change interval to fit with the monitored/observed data during calibration and validation (Figure 3). ESCO, GWQMN, and SURLAG were three key parameters in the process of calibration \& validation of water flow (Shen et al., 2010; Francos et al., 2003). The other sensitive parameters selected for calibration \& validation in HTRW were showed in Figure 3. In the HTRW, Liaoning Province government began to monthly monitoring of pollutant since 2006. The runoff, TN \& TP loadings data used for calibration \& validation were from 1992 to 2009, from 2006 to 2008, respectively. 
runoff hydrograph, $D v$ (relative deviation), $E_{N S}$ and $R^{2}$ (certainty coefficient). The runoff hydrograph and $D v$ were frequently used to simulate the entire deviation of water quantity; $E_{N S}$ and $R^{2}$ were used to simulate the effects of the simulation (Yang et al.,2014). The $D v, E_{N S}$ and $R^{2}$ are calculated as

$$
D_{v}=[(M-W) / W] \times 100 \%
$$

Here, $D_{v}$ was the relative deviation; $W$ was the observed mean value; and $M$ was the predicted mean value.

$$
E_{N S}=1-\left[\sum_{i=1}^{n}\left(W_{i}-M_{i}\right)^{2} / \sum_{i=1}^{n}\left(W_{i}-\bar{W}\right)^{2}\right]
$$

Here, $E_{N S}$ was the Nash-Sutcliffe efficiency coefficient; $W_{i}$ was the observed data at $i^{\text {th }}$ period; $M_{i}$ was the simulated data at $i^{\text {th }}$ period; and $\bar{W}$ was the observed mean value.

$$
R^{2}=\left\{\left[\sum_{i=1}^{n}\left(W_{i}-\bar{W}\right)\left(M_{i}-\bar{M}\right)\right] /\left[\sqrt{\sum_{i=1}^{n}\left(W_{i}-\bar{W}\right)^{2}} \sqrt{\sum_{i=1}^{n}\left(M_{i}-\bar{M}\right)^{2}}\right]\right\}^{2}
$$

Here, $R^{2}$ was the certainty coefficient; $W_{i}$ was the observed value at time $i ; M_{i}$ was the simulated value at time $i ; \bar{W}$ was the observed mean value, and $\bar{M}$ was the predicted mean value.

The first four years (1990-1994) were regarded as domestication stage of SWAT to minimize the uncertainty of initial meteorology \& underlying surface value. We used manual method of parameter adjustment to calibrate the SWAT in HTRW. To determine the sensitivity of various parameters, we manually adjusted one parameter at a time according to the accuracy and change interval in Figure 3 . To realize the matching between hydrographs base flow from model simulation and actual monitoring, the quantitative data analysis technology $\left(E_{N S} \& R^{2}\right)$ was used to calibrate SWAT. In order to calibrate the stream flow, we subsequently calibrated runoff, and nutrients (TP \& TN) with the same geographical and hydrological data. During calibration, we used LOADEST model to eliminate the uncertainties caused by the differences in sampling \& testing methods of water quality (Yang et al.,2014).

\subsection{Scenarios setting}

To seek the relationship between agricultural NPS pollutant loading and land use types, comprehensive comparison method was used in different land use types under urbanization. In this study, two scenarios were established: status quo scenario, and "environmental protection" scenarios (EPS). 
Hydrol. Earth Syst. Sci. Discuss., https://doi.org/10.5194/hess-2017-755

The status quo scenario was formulated based on the existing socio-economy developmental structure and environmental protection measures, and the land use type in the light of the existing developmental model and planning conditions. The BMPs information \& land use data (cultivated land area, pesticide \& fertilizer use utility amount, crop type) were obtained from Liaoning Province statistical yearbooks-2013 and field survey.

Considering the regional development prospects \& eco-environment protection strategy in HTRW, the EPS was proposed. $1 \mathrm{~km}$ within both banks of the Hunhe, Taizi and Daliao rivers and $5 \mathrm{~km}$ surrounding reservoirs are defined as buffer zones. In the buffer zones, existing land use types were changed to restore the natural environment (grassland and forest). The output of pollutant production is calculated based on the regional environmental protection. This scenario not only preserves the fundamental position of agriculture in the watershed, but also improve the ecosystem service value of the watershed by only slightly reducing the amount of fertilizers and pesticides used for agricultural production. The scenarios setting can provide scientific basis for further understanding characteristics of the nitrogen and phosphorus loadings and agricultural structure adjustment in HTRW.

\subsection{Study framework}

Hunhe River, Taizi River, and Daliao River sub catchment was delineated based on DEM \& river system, and further divided by 29 small calculation modules according to 184 HRUs, water resources zoning, and administrative zoning. According to the water network \& the location of basin drainage, we used the monitored data calibrate \& validate the stream flow and concentration changes of pollutants in HTRW. And then the land development patterns in two scenarios were imported to SWAT model to simulate the TN and TP pollution loading. Finally, the NPS pollution loading decrease was analyzed based on land use scenarios.

The primary source area of aquatic pollution is mainly distributed along both channels of the trunk stream of the Hunhe River, Taizi River, and Daliao River; the risk of NPS pollution is mainly related to the patterns of agricultural plantation and farmland utilization. The secondary source area of aquatic pollution is mainly distributed along the tributaries of HTRW. Therefore, this project paid special attention to the pollutant 
Hydrol. Earth Syst. Sci. Discuss., https://doi.org/10.5194/hess-2017-755

production in the agricultural lands adjacent to the water channels.

\section{Results \& discussions}

\subsection{Modelling validation}

Stream flow. Because of HTRW lacks basic runoff data, the present study focused on calibrating and testing the runoff model. During annual calibration, the runoff curve data were first calibrated, and then the available water content in the soil and the soil evaporation compensation coefficient were modified until they matched the requirements for runoff. Finally, the monthly runoff curve was modified. For the simulation, 1990-1994 was the model preparation period, 1995-2001 was the model calibration period, and 2002-2009 was the model validation period.

According to the calibration results, $E_{N S}$ and $R^{2}$ for Xingjiawopeng hydrological station and Tangmazhai hydrological station were both greater than 0.6 , and the $|D v|$ values for both stations were less than $20 \%$ during the model preparation period, suggesting that the parameters of the SWAT model were reliable after calibration, and thus the model can be used for further study. The monitoring value fitted very well with the simulation value obtained from hydrographic curve, most crest values observed were very similar. In the model calibration period, the matching curves for the simulated and measured values of monthly runoff at Xingjiawopeng and Tangmazhai hydrological stations are shown in Figure 4 (a) and Figure 4 (b). The runoffs at these two hydrological stations were well matched. However, the accuracy of the runoff in the second half of the year in 2002, 2005 and 2006 was poor, likely due to the length of the data series and specific stations selected. In terms of the standards for the simulation and evaluation of the hydrological model, the simulation effects at the monthly scale were much better.

Nutrients. The nutrients concentrations of water were simulated by SWAT. Based on the verification of the accuracy of the initial concentrations, the fertilization and cultivation measures for nutrients in the soil, the nitrate and soluble $\mathrm{P}$ loading can be simulated by adjusting the nitrogen permeability coefficient (NPERCO) and the phosphorous permeability coefficient (Lam et al., 2011). Beikouqian, Xingjiawopeng, Xiaolinzi and Tangmazhai four hydrological stations had a continuous monthly water quality monitoring 
Hydrol. Earth Syst. Sci. Discuss., https://doi.org/10.5194/hess-2017-755

data from 2006 to 2007. Only the monthly data of TN \& TP in Beikouqian were validated from 2008 to 2009 for the insufficient of water quality monitoring data. The Xingjiawopeng, Xiaolinzi and Tangmazhai Hydrological Stations only had the TN data in the study time. Therefore, Beikouqian was selected to show validation curves, the TN $E_{N S}$ and $R^{2}$ were 0.64 and 0.78 , and the TP $E_{N S}$ and $R^{2}$ were 0.60 and 0.75 , respectively (Figure 5(a), Figure 5(b)). The calculation results of $E_{N S}$ and $R^{2}$ of Xingjiawopeng, Xiaolinzi and Tangmazhai hydrological stations were 0.62 and $0.73,0.61$ and 0.72 , as well as 0.62 and 0.77 , respectively. The values of all $R^{2}$ were higher than 0.7 , which confirmed the SWAT could be used for water quality simulation in HTRW.

\subsection{NPS pollutant loading under status quo scenario}

The output of NPS pollutant production was calculated using the pollutant loading approach based on the attributes of the regional calculation results and land use scenarios in HTRW. The output of N \& P production in different calculation units were calculated based on the spatial changes of soil types, crops and residuals, as well as the differences in the coefficients of $\mathrm{N} \& \mathrm{P}$ losses under different land use types. The paddy fields, rural residential, urban development, and vegetation type maybe the important indicators for variability in NPS pollution, and that nutrition pollution was influenced by the integrated effects of different land uses (Cai et al., 2015; Lee et al.,2010). The annual throughputs of TN \& TP production were $18707 \mathrm{t}$ and53 $322 \mathrm{t}$, respectively (Table 1).

\subsubsection{Sediment}

The sediment loading is the data basis to calculate the TN \& TP loading, and which is affected by the type of land development and vegetation coverage (which was generally dominated by forest and farmland). Based on the simulation by the SWAT model, the annual output of sediment (silt) production in the watersheds of the Hunhe, Taizi and Daliao rivers was $22 \times 10^{4} \mathrm{t}, 170 \times 10^{4} \mathrm{t}$ and $30 \times 10^{4} \mathrm{t}$, respectively. The annual soil erosion modulus in the study area was $0.811 \mathrm{t} / \mathrm{ha}$, and its spatial distribution is shown in Figure 6(a). The soil erosion (sediment) value varied widely in different regions, with the change interval from 0 to 1.824 t/ha. Soil erosion in Daliao River watershed was very serious (with up to $1.568 \mathrm{t} / \mathrm{ha}$ in some 
Hydrol. Earth Syst. Sci. Discuss., https://doi.org/10.5194/hess-2017-755

Manuscript under review for journal Hydrol. Earth Syst. Sci.

Discussion started: 10 January 2018

(c) Author(s) 2018. CC BY 4.0 License.

regions), followed by the Taizi River watershed (The amount was $1.223 \mathrm{t} / \mathrm{ha}$ in most regions) and Hunhe River watershed (Less than 0.19 t/ha in most regions). Yingkou and Dashiqiao has even topography, and ncoming silt from the upper reaches is accumulated therein. The soil erosion modulus is therefore very high, which contributes greatly to the silt inputs to the HTRW (Tang et al.,2012). The soil erosion was affected by natural \& human factors. The natural factors mainly included topography, underlying surface conditions and soil types, the human factors mainly consisted of vegetation coverage, precipitation type, and use, crop cultivation and cultivated land farming methods. Moreover, mountainous area has great soil erosion (Hong et al.,2012). The HTRW had high forest coverage, which effectively prevented the soil erosion. Daliao rivers had a large area of cultivated land, therefore, there was higher probability to cause soil erosion. Besides, the soil types are also the key influencing factors to cause soil erosion, therefore, the rown and paddy soils are prone to bring about the accumulation of sediment (Hong et al.,2012).

\subsubsection{TP}

With SWAT simulation results, the annual output of TP production in the watersheds of the Hunhe, Taizi and Daliao rivers was 8993 t, 6399 t and 3315 t, respectively, the watershed loading output intensity was $7 \mathrm{~kg} / \mathrm{ha}$. The TP loading had the same spatial distribution pattern with the sediment loading. The TP loading ranged from 0 to $259.83 \mathrm{~kg} / \mathrm{ha}$. Figure $6(\mathrm{~b})$ showed the spatial variation of TP loading the HTRW. The average annual water volume was affluent in Hunhe River, which prompted a large amount of P deposited in the downstream plain. The changes in space of the TP loading was affected by topography, precipitation, land use type, and silt losses. The TP loading output intensity of on the slope in the Daliao River watershed was higher than that in the Hunhe River watershed, and the Taizi River watershed was the lowest. Large amounts of fertilizer and pesticides have been applied to the farmland. Organophosphate pesticides accounted for $40 \%$ of the total pesticides. Therefore, the farmland has high TP concentrations, which was the same findings with Wang (2012). The paddy fields, brown soil and dry lands mainly distributed in Hunhe River downstream, therefore, the P loading in these plain area is higher ( $\mathrm{Li}$ et al., 2010). Correspondingly, the cities and counties 
with a large proportion of farmland, such as Dashiqiao, Panshan and Dawa city in the Daliao River watershed, as well as the city of Haicheng and Taian county in the Hunhe River watershed, have higher TP loading output intensity. The regions with a large proportion of developed land, such as the city center of Fushun, Shenyang in Hunhe River watershed, the municipal districts of Liaoyang city and Benxi city at the Taizi River watershed, which have lower TP loading output intensities. Based on the land use type, the tributaries with a higher proportion of farmland have the highest TP output intensities, whereas the tributaries with substantial vegetation cover as forested land have relatively lower TP output intensities. The output intensity of TP is closely related to soil characteristics and attributes.

\subsubsection{TN}

Upon simulation and calculation, the output of TN production in the watersheds of the Hunhe, Taizi and Daliao rivers was 24264 t, $19010 \mathrm{t}$ and $10048 \mathrm{t}$. The annual loading output intensity of $\mathrm{TN}$ in the watershed was $19 \mathrm{~kg} / \mathrm{ha}$. Figure 6(c) showed the spatial variation of TN loading the HTRW. The TN loading varied interval from 0.001 to $365.36 \mathrm{~kg} / \mathrm{ha}$. The TN loading had the same spatial characteristics with TP loading. The loading output intensity of TN in the Daliao River watershed was greater than that in the Hunhe River watershed, and the Taizi River watershed was the lowest. Large amounts of fertilizer were applied in the study area. Nitrate and organic $\mathrm{N}$ accounted a substantial portion of the fertilizer used in HTRW. Therefore, the loading output intensity of TN in the watershed was very high. The regions with a great proportion of farmland, such as the middle \& lower reaches of the Hunhe River, the lower reaches of the Taizi River and the tributaries in the upper reaches of the Daliao River, have high output intensities of TN. The organic N contents in forested land was very low. Thus, the output intensity of $\mathrm{TN}$ in regions with high vegetation cover of forest, such as the mountainous area in 
the upper reaches of the Taizi and Hunhe rivers, was very low. The output loading intensity of TN in the municipal districts with high developed area was the lowest, such as the municipal districts of Fushun city and Shenyang city in the Hunhe River watershed, and the municipal districts of Benxi city, Liaoyang city and Shenyang city in the Taizi River watershed.

The loading intensity of TN \& TP in the HTRW were characterized by its regional distribution. Although the counties of Qingyuan, Yibin and Benxi county, located in the upper reaches of the HTRW, had high output of water and silt, their loading intensities of pollution were not high. From the unit area perspective, the maximum loading intensities of TN \& TP were $365.36 \& 259.83 \mathrm{~kg} / \mathrm{ha}$, respectively. The regions with high loading intensities of TN \& TP were mainly distributed in Taian, Haicheng, and Fushun city. The loading intensities of TP $\&$ TN near the Dahuofang, Tanghe, Shenwo and Tanghe reservoirs were not high, ranging from 0.006 to $9.584 \mathrm{~kg} / \mathrm{ha}$, from 0.08 to $19.485 \mathrm{~kg} / \mathrm{ha}$, respectively. Based on the topography and soil type distribution, the gradient in the upper stream of HTRW was usually high. The soil type is predominately brown soil and salted paddy soil, both of which are easily eroded. The topography in the lower reaches is usually even, as in the cities of Anshan, Haicheng, Yingkou and Panjin. The elevation is not high, and the soil type is usually predominately meadow soil and brown soil, both of which have a higher soil erosion rate, silt loss and loading intensity of pollutants. The regions with heavy loading intensities of TN \& TP included Xinmin county, located in the middle and lower reaches of the HTRW, the municipal district of Shenyang city, Liaozhong county, Dengta city, Liaoyang county, the municipal district of Anshan city, Haicheng city and a portion of Dashiqiao city. Based on the land development pattern in the Taizi River, dry fields and paddy fields were mainly distributed on the plain area of this watershed, which is therefore a core source of loading intensity. The spatial difference in the 
loading intensity between TN \& TP were inconspicuous. Based on the topography, landform, soil types and land development status in the watershed, the upper stream of watershed have high vegetation coverage, less farmland and a low loading intensity of pollutants; the lower reaches of the watershed have more farmland, high rates of fertilizer application and a high soil erosion and pollution loading (Yin et al.,2011). To sum up, the spatial characteristics of TN loading was the result of comprehensive effect from precipitation/run off characteristics, soil properties, soil erosion and vegetation coverage. Therefore, in order to effectively control TN loading and soil erosion in the HTRW, the BMPs, fallow measures of cultivated fields, watershed vegetation restoration and soil \& water conservation in the upper stream, which were the most important measure that should be implemented.

\subsection{NPS pollutant loading under EPS}

The prevalence of farmland within a watershed has long been an important question, and strong evidence exists of a correlation between land development mode and water environment protect \& rehabilitation at the basin scale. Numerous studies have used land use data and stepwise regression analysis to explore relationships between land use and water quality parameters and ecological integrity on a regional scale, including sub-basins, river riparian buffer zones, and specific monitoring sites (Uriarte et al., 2011; Schiff, 2007; King et al., 2005). The riparian buffer zones could effectively reduce the concentration levels of $\mathrm{NO}_{3}{ }^{-}$in water, which was $47 \%$ lower than the soil content (Venkatachalam et al.,2005). The dry farmland caused a higher NPS pollutant loading, followed by paddy, rural and urban area, forest land, and shrub land. Under this developmental scenario, the area of farmland in the watershed was reduced; a modest area of farmland (29 500 ha, accounting for $2.74 \%$ of the total farmland area) was converted to forestland (included shrub land, 14753 ha), grassland (5 899 ha), wetland ( 8 
Hydrol. Earth Syst. Sci. Discuss., https://doi.org/10.5194/hess-2017-755

Manuscript under review for journal Hydrol. Earth Syst. Sci.

Discussion started: 10 January 2018

$848 \mathrm{ha}) ;$ and NPS pollution from farmland decreased. The objective of water quality protection within the critical zoning of the watershed was realized. For the riparian buffers can be planted in various diverse vegetation, the $\mathrm{N}$ removal rate of $60 \mathrm{~m}$ wide woody soil buffer zone was $16 \%$ and 38\% higher than that of shrubbery and grassland, respectively (Aguiar et al.,2015). Urban \& rural areas were considered as the same type of land use in SWAT, about 1 kilometer within both banks of the tributaries of the Hunhe, Taizi and Daliao rivers and 5 kilometers surrounding reservoirs were defined as buffer zones, including $1946 \mathrm{~km}^{2}$ of farmland, urban land, and rural residential land, which accounts for $7.1 \%$ of the total area in the watershed. The woodland coverage rate was reduced by $1 \%$, the loading intensity of sediment, TP \& TN increased by $0.01 \sim 11.34,0.15$ 2.83, and $0.40-14.00 \mathrm{~kg} / \mathrm{km}^{2}$, respectively. The output of pollutant production under EPS was calculated by transforming the existing land use type.

Based on the parameter quantification results of SWAT, the TN \& TP losses from farmland was effectively reduced after the modification of the land use structure. TN \& TP respective range of change was from 0 to $365.357 \mathrm{~kg} / \mathrm{ha}$, and from 0 to $259.834 \mathrm{~kg} / \mathrm{ha}$. The annual losses of TN \& TP were reduced by 13839 and 1946 t/a, respectively. In comparison, the output of NPS pollutant production under the EPS was decreased by $21.9 \%$ compared with that under the status quo scenario, whereas the outputs of TP \& TN were reduced by $10.4 \%$ and $25.9 \%$, respectively. Under EPS, the average loading intensities of TN \& TP were 14 and $6 \mathrm{~kg} / \mathrm{ha}$ on a unit area basis, which were $14.3 \%$ and $26.3 \%$ less than the loading intensities under status quo scenario. The NPS pollution loading decline obviously in the EPS. The variation of TP \& TN pollution loading between status quo and EPS was shown in Table 2. The amount change indicated that riparian buffer and land development pattern change could effectively reduce the NPS pollutant loading in the HTRW. 


\section{Conclusions}

The NPS pollution is prone to cause in dry farmland, paddy, rural \& urban areas. The SWAT model has been applied to study NPS in China by numerous research literature, they were mainly focuses on scenario simulation of NPS pollution and management in agricultural areas with rich hydrological and meteorological data. The basic monitoring data of HTRW were deficient, we selected the SWAT as the feasible method to access NPS pollutant loading in watershed level. We applied certain practices based on EPS to reduce the NPS pollutant loading in the Hunhe River, Taizi River and Daliao River watershed. The status quo scenario and EPS were used to calculate the output of NPS pollutant production. Under the status quo scenario, the soil erosion modulus in the HTRW was $0.811 \mathrm{t} / \mathrm{ha}$, and the soil erosion in the Daliao River watershed was the most severe. The TP \& TN annual loading in the HTRW was 19, and $7 \mathrm{~kg} / \mathrm{ha}$, respectively. In the middle and lower stream of HTRW has a higher NPS pollutant loading, which included the urbanization and population density highly region of Shenyang, Anshan and Liaoyang. Under the EPS, the TN \& TP per unit area were 14, and $6 \mathrm{~kg} / \mathrm{ha}$, respectively. The output of NPS pollutant production, the loading intensities of TN \& TP was reduced by $21.9 \%, 25.9 \%$ and $10.4 \%$ compared with the status quo scenario, respectively. In different regions of NPS pollutant loading in the HTRW changes greatly, and the pollutant loading intensity of different nutrients in the same region is slightly different. Land ecorestoration and land development mode adjustment measures should be practiced to reduce NPS pollutant loading of cultivated land.

The SWAT model can be used to calculate and access the source, and potential reduction of agricultural NPS pollutants based on different land use type. The reliability of SWAT evaluation results is decided by information completeness and the reasonable degree of 
parameter initialization. In HTRW some data were missing, such as the rainfall intensity, and water pollution, et al. The data inaccuracy and local factors has a certain impact on SWAT model accession result. To determine the pollutant reduction under different land development patterns, and examine uncertainty of sensitivity parameters, SWAT model in China has wide range of potential application.

Acknowledgements The study was financially supported by the National Key Research and Development Program of China (2016YFC0401408) and Project Based Personnel Exchange Program with China Scholarship Council \& German Academic Exchange Service of 2015. The author appreciates the experts \& scholars of Helmholtz Centre for Environmental Research UFZ (Leipzig, Germany), as well as anonymous reviewers for their valuable comments and criticisms.

\section{References}

Abbaspour, K.C., Yang, J., Maximov, I., Siber, R., Bogner, K.: Modelling hydrology and water quality in the pre-alpine/alpine Thur watershed using SWAT, J. Hydrol., 333, 413-430, 2007.

Aguiar, T.R., Rasera, K., Parron, L.M., Brito, A.G., Ferreira, M.T.: Nutrient removal effectiveness by riparian buffer zones in rural temperate watersheds: The impact of no-till crops practices, Agric. Water Management, 149,74-80, 2015.

Ahearn, D.S., Sheibley, R.W., Dahlgren, R.A.: Land use and land cover influence on water quality in the last free flowing river draining the western Sierra Nevada, California, J. Hydrol., 313, 234-247, 2005.

Arnold, J.G., Moriasi, D.N., Gassman, P.W., Abbaspour, K.C., White, M.J.: SWAT: model use, calibration, and validation, Trans ASABE, 55, 1491-1508, 2012.

Arnold, J.G., Srinivasan, R., Muttiah, R.S.: Large area hydrologic modelling and assessment. Part I: Model development, Journal of the American Water Resources Association, 34, 7389, 1998. 
Hydrol. Earth Syst. Sci. Discuss., https://doi.org/10.5194/hess-2017-755

Cai,Y., Zhao, D.H., Xu, D.L., Jiang, H., Yu, M.Q.: Influences of Land Use on Sediment Pollution across Multiple Spatial Scales in Taihu Basin, Clean-Soil, Air, Water, 43, 16161622, 2015.

de Oliveira, L.M., Maillard, P., de Andrade Pinto, E.J.: Modeling the effect of land use/land cover on nitrogen, phosphorous and dissolved oxygen loads in the Velhas River using the concept of exclusive contribution area, Environ Monit Assess., 188, 333-351, 2016.

Department of Environmental Protection of Liaoning Province: Liaoning Province Environmental Bulletin, 2011.

Dingman, S.L.: Physical hydrology: Waveland press, 2002.

Douglas-Mankin, K.R., Srinivasan, R., Arnold, J.G.: Soil and Water Assessment Tool (SWAT) model: Current developments and applications, T ASABE, 53, 1423-1431, 2010.

Ficklin, D.L., Luo, Y.Z., Luedeling, E., Zhang, M.H.: Climate change sensitivity assessment of a highly agricultural watershed using SWAT, J. Hydrol., 374, 16-29, 2009.

Francos, A., Elorza, F.J., Bouraoui, F., Bidoglio, G., Galbiati, L.: Sensitivity analysis of distributed environmental simulation models: understanding the model behaviour in hydrological studies at the catchment scale, Reliab Eng Syst Saf., 79, 205-218, 2003.

Gassman, P.W., Reyes, M.R., Green, C.H., Arnold, J.G.: The Soil and Water Assessment Tool: Historical development, applications and future directions, Trans ASABE, 50, 1211-1250, 2007.

Geng, R.Z., Li, M.T., Wang, X.Y.: Effect of land use/landscape changes on diffuse pollution load from watershed based on SWAT model, Transactions of the Chinese Society of Agricultural Engineering, 31, 241-250, 2015.

Gosain, A.K., Rao, S., Srinivasan, R.: Return-flow assessment for irrigation command in the Palleru River Basin using SWAT model, Hydrol Process, 19, 673-682, 2005.

Hong, Q., Sun, Z., Chen, L., Liu, R., Shen, Z.: Small-scale watershed extended method for nonpoint source pollution estimation in part of the Three Gorges Reservoir Region, Int $\mathrm{J}$ Environ Sci Technol., 9, 595-604, 2012.

Hundecha, Y., Bárdossy, A.: Modeling of the effect of land use changes on the runoff generation of a river basin through parameter regionalization of a watershed model, J. Hydrol., 292, 281-295, 2004.

King, R.S., Baker, M.E., Whigham, D.F., Weller, D.E.: Spatial Considerations for Linking 
Hydrol. Earth Syst. Sci. Discuss., https://doi.org/10.5194/hess-2017-755

Watershed Land Cover to Ecological Indicators in Streams, Ecol. Appl., 15, 137-153, 2005. Kuai, P., Li, W., Liu, N.: Evaluating the Effects of Land Use Planning for Non-Point Source Pollution Based on a System Dynamics Approach in China, PLOS ONE 10, e0135572. doi:10.1371/ journal. pone.0135572, 2015.

Lam, Q.D., Schmalz, B., Fohrer, N.: The impact of agricultural Best Management Practices on water quality in a North German lowland catchment, Environ Monit Assess, 183, 351-379, 2011.

Lee, M.S., Park, G.A., Park, M.J.: Evaluation of non-point source pollution reduction by applying Best Management Practices using a SWAT model and Quick Bird high resolution satellite imagery, Journal of Environmental Sciences, 22, 826-833, 2010.

Li, M., Zhu, B., Hou, Y.L.: Phosphorus release risk on a calcareous purple soil in southwest China, Int J Environ Pollut., 40, 351-362, 2007.

Lindenschmidt, K.E., Fleischbein, K., Baborowski, M.: Structural uncertainty in a river water quality modelling system, Ecological Modelling, 204, 289-300, 2007.

Liu, M., Li, C.L., Hu, Y.M., Sun, F.Y.: Combining CLUE-S and SWAT Models to Forecast Land Use Change and Non-Point Source Pollution Impact at a Watershed Scale in Liaoning Province, China. Chin. Geogra. Sci., 24, 540-550, 2014.

Liu, X., Wang, S., Xue, H., Singh, V.P.: Simulating Crop Evapotranspiration Response under Different Planting Scenarios by Modified SWAT Model in an Irrigation District, Northwest China, PLOS ONE 10(10), e0139839. doi: 10.1371/journal.pone.0139839., 2015.

Logsdon, R.A., Chaubey, I.: A quantitative approach to evaluating ecosystem services, Ecological Modelling, 257, 57-65, 2013.

Mapfumo, E., Chanasyk, D.S., Willms, W.D.: Simulating daily soil water under foothills fescue grazing with the soil and water assessment tool model (Alberta, Canada), Hydrol Process, $18,2787-2800,2004$

McElroy, A.D., Chui, S.Y., Nebgen, J.W., Aleti, A., Bennet, F.W.: Load Functions for Assessment of Water Pollution from Non Point Sources, EPA Document EPA 600/2-76151, USEPA, Athens, USA, 1976.

Nash, J.E., Sutcliffe, J.V.: River flow forecasting through conceptual models part I-A discussion of principles, J Hydrol.,10, 282-290,1970.

Neitsch, S.L., Arnold, J.G., Kiniry, J.R., Williams, J.R., King, K.W.: Soil and Water Assessment 
Hydrol. Earth Syst. Sci. Discuss., https://doi.org/10.5194/hess-2017-755

Tool: Theoretical Documentation, version (available at http://www.brc.tamus.edu/swat/), 2005.

Niraula, R., Kalin, L., Srivastava, P., Anderson, C.J.: Identifying critical source areas of nonpoint source pollution with SWAT and GWLF, Ecological Modelling, 268, 123-133, 2013.

Outram, F.N., Cooper, R.J., S"unnenberg, G., Hiscock, K.M., Lovett, A.A.: Antecedent conditions, hydrological connectivity and anthropogenic inputs: factors affecting nitrate and phosphorus transfers to agricultural headwater streams, Sci Total Environ., 545, 184$199,2016$.

Ouyang, W., Huang, H., Hao, F.: Synergistic impacts of land-use change and soil property variation on non-point source nitrogen pollution in a freeze-thaw area, J. Hydrol., 495, $126-134,2013$

Ouyang, W., Skidmore, A., Toxopeus, A., Hao, F.: Long-term vegetation landscape pattern with non-point source nutrient pollution in upper stream of yellow river basin, J. Hydrol., 389, 373-380, 2010.

Ouyang, W., Wang, X., Hao, F.: Temporal-spatial dynamics of vegetation variation on non-point source nutrient pollution, Ecological Modelling, 220, 2702-2713, 2009.

Quilb'e, R., Rousseau, A.N., Duchemin, M., Poulin, A., Gangbazo, G.: Selecting a calculation method to estimate sediment and nutrient loads in streams: application to the beaurivage river (qu'ebec, Canada), J. Hydrol., 326, 295-310, 2006.

Robinson,T.H., Leydecker, A., Keller, A.A.: Steps towards modeling nutrient export in coastal Californian streams with a Mediterranean climate, Agricultural Water Management, 77, $144-158,2005$

Sadeghi, S.H.R., Jalili, K., Nikkami, D.: Land use optimization in watershed scale, Land Use Policy, 26, 186-193, 2009.

Schiff, R., Benoit, G.: Effects of Impervious Cover at Multiple Spatial Scales on Coastal Watershed Streams, J. Am. Water Resour. Assoc., 43, 712-730, 2007.

Seppelt, R., Voinov, A.: Optimization methodology for land use type using spatially explicit landscape models, Ecological Modelling, 151, 125-142, 2002.

Shen, Z., Chen, L., Hong, Q., Xie, H., Qiu, J.: Vertical Variation of Nonpoint Source Pollutants in the Three Gorges Reservoir Region, PLOS ONE, 8, e71194. 
Hydrol. Earth Syst. Sci. Discuss., https://doi.org/10.5194/hess-2017-755

doi:10.1371/journal.pone.0071194, 2013a.

Shen, Z.Y., Chen, L., Hong, Q.b., Qiu, J.L.: Assessment of nitrogen and phosphorus loads and causal factors from different land use and soil types in the Three Gorges Reservoir Area, Sci Total Environ., 454, 383-392, 2013 b.

Shen, Z., Chen, L., Xu, L.A.: Topography Analysis Incorporated Optimization Method for the Selection and Placement of Best Management Practices, PLOS ONE, 8, e54520. doi: 10.1371/journal.pone.0054520, 2013c.

Shen, Z.Y., Hong, Q., Yu, H., Niu, J.F.: Parameter uncertainty analysis of non-point source pollution from different land use type, Sci Total Environ., 408, 1971-1978, 2010.

Shen, Z.Y., Liao, Q., Hong, Q., Gong, Y.W.: An overview of research on agricultural non-point sources pollution modelling in China, Sep Purif Technol., 9, 595-604, 2011.

Tang, J., Liu, C., Yang, W.: Spatial Distribution of Non-Point Source Pollution in Dahuofang Reservoir Catchment Based on SWAT Model, Scientia Geographica Sinica, 32, 1247-1253, 2012.

Tucci, C.E.: Modelos hidrol'ogicos, Porto Alegre: UFRGS, 1998.

Uriarte, M., Yackulic, C.B., Lim, Y.L., Arce-Nazario, J.A.: Influence of Land Use on Water Quality in a Tropical Landscape-a Multi-Scale Analysis, Landscape Ecol., 26,1151-1164, 2011.

USDA Soil Conservation Service: National Engineering Handbook. U.S. Government Printing Office, Washington, DC, Hydrology Section 4 (chapters 4-10), 1972.

USGS: Load Estimator (LOADEST): A Program for Estimating Constituent Loads in Streams and Rivers, http://water.usgs.gov/software/loadest, 2013.

Venkatachalam, A., Jay, R., Eiji, Y.: Impact of riparian buffer zones on water quality and associated management considerations, Ecol. Eng., 24, 517-523, 2005.

Wang, G., Yang, H., Wang, L., Xu, Z., Xue, B.: Using the SWAT model to assess impacts of land use changes on runoff generation in headwaters, Hydrol Process, 28, 1032-1042, 2014.

Wang, X.L., Wang, Q., Wu, C.Q., Liang, T., Zheng, D.H., Wei, X.F.: A method coupled with remote sensing data to evaluate non-point source pollution in the Xin'anjiang catchment of China, Sci Total Environ., 430, 132-143, 2012.

Williams, J.R., Hann, R.W.: Optimal Operation of Large Agricultural Watersheds with Water Quality Constraints, Technical Report No. 96, Texas Water Resources Institute, Texas 
Hydrol. Earth Syst. Sci. Discuss., https://doi.org/10.5194/hess-2017-755

Manuscript under review for journal Hydrol. Earth Syst. Sci.

Discussion started: 10 January 2018

(c) Author(s) 2018. CC BY 4.0 License.

A\&M University, 1978.

Williams, J.R.: Sediment routing for agricultural watersheds, Water Resour. Bull., 11, 965-974, 1975.

Yang, J., Reichert, P., Abbaspour, K.C., Xia, J., Yang, H.: Comparing uncertainty analysis techniques for a SWAT application to the Chaohe Basin in China, J Hydrol., 358, 1-23, 2008.

Yang, J.L., Zhang, G.L., Zhao, Y.G.: Land use impact on nitrogen discharge by stream: a case study in subtropical hilly region of China, Nutrient Cycling in Agroecosystems, 77, 29-38, 2007.

Yang, Y., Wang, G., Wang, L., Yu, J., Xu, Z.: Evaluation of Gridded Precipitation Data for Driving SWAT Model in Area Upstream of Three Gorges Reservoir, PLOS ONE, 9, e112725. doi: 10.1371/journal.pone.0112725, 2014.

Yin, G., Wang, N., Yuan, X.: Non-point source pollution of nitrogen and phosphorus nutrients using SWAT model in tumen river watershed, China, Journal of Agro-Environment Science, 30, 704-710, 2011.

Zhang, Y.H.: Development of Study on Model-SWAT and Its Application, Progress in Geography, 24, 121-130, 2005. 
Hydrol. Earth Syst. Sci. Discuss., https://doi.org/10.5194/hess-2017-755

Manuscript under review for journal Hydrol. Earth Syst. Sci.

Discussion started: 10 January 2018

(c) Author(s) 2018. CC BY 4.0 License.

Figure captions:

639 Figure 1. Basic information on the HTRW. The figure has been supplied by www.geodata.cn,

640 which is a national science and technology basic conditions platform and an earth system

641 science data sharing platform. The figure information is public. The Liaoning province Water

642 Resources Administrative Bureau granted permission for the basic information in the HTRW.

643 Figure 2. Data information in the HTRW.

644 Figure 3. Parameters calibration of SWAT model in the HTRW

645 Figure 4. The stream flow validation result of typical monitoring station.

646 Figure 5. The nutrients validation in Beikouqian station.

647 Figure 6. NPS pollution loading distributions of HTRW under status quo scenario. 
Hydrol. Earth Syst. Sci. Discuss., https://doi.org/10.5194/hess-2017-755

Manuscript under review for journal Hydrol. Earth Syst. Sci.

Discussion started: 10 January 2018

Table 1. The pollutant production in the HTRW under status quo scenario

\begin{tabular}{lcccccccc}
\hline Watershed & $\begin{array}{c}\text { Area } \\
\left(\mathrm{km}^{2}\right)\end{array}$ & $\begin{array}{c}\text { Run off } \\
\left(\mathrm{E}+08 \mathrm{~m}^{3}\right)\end{array}$ & \multicolumn{3}{c}{ Pollutant (t) } & \multicolumn{3}{c}{$\begin{array}{c}\text { Pollutant loading } \\
(\mathrm{kg} / \mathrm{ha})\end{array}$} \\
& & & Sediment & TP & TN & Sediment & TP & TN \\
\hline Hunhe River & 11565 & 24.04 & 220004 & 8993 & 24264 & 190 & 8 & 21 \\
Taizi River & 13903 & 33.31 & 1699996 & 6399 & 19010 & 1223 & 5 & 14 \\
Daliao River & 1913 & 1.60 & 300002 & 3315 & 10048 & 1568 & 17 & 53 \\
Total/Average & 27381 & 58.95 & 2220002 & 18707 & 53322 & 811 & 7 & 19 \\
\hline
\end{tabular}

Source: China Hydrology; National earth system data sharing infrastructure; Field investigation of Liaoning province; Chemical fertilizer/Land area/Soil erosion statistics yearbook of Liaoning province; Liaoning province bureau of Meteorology.

Table 2. The variation of TP \& TN pollution loading between EPS and status quo scenario

\begin{tabular}{lccccccccccc}
\hline \multicolumn{1}{c}{ Watershed } & $\begin{array}{c}\text { Pollutant loading of } \\
\text { EPS (kg/ha) }\end{array}$ & \multicolumn{2}{c}{$\begin{array}{c}\text { Pollutant loading } \\
\text { variation }(\mathrm{kg} / \mathrm{ha})\end{array}$} & $\begin{array}{c}\text { Farmland } \\
\text { variation } \\
\text { TP }\end{array}$ & TN & TP & TN & $\begin{array}{c}\text { Forestland } \\
\text { variation } \\
\text { (ha) }\end{array}$ & $\begin{array}{c}\text { Grassland } \\
\text { variation } \\
\text { (ha) }\end{array}$ & $\begin{array}{c}\text { Wetland } \\
\text { variation } \\
\text { (ha) }\end{array}$ & $\begin{array}{c}\text { Pollutant annual } \\
\text { variation(t/a) }\end{array}$ \\
\hline Hunhe River & 7 & 16 & -1 & -5 & -12460 & +6231 & +2492 & +3737 & -838 & -5743 \\
Taizi River & 4 & 10 & -1 & -4 & -14979 & +7491 & +2995 & +4493 & -776 & -5606 \\
Daliao River & 16 & 40 & -1 & -13 & -2061 & +1031 & +412 & +618 & -332 & -2490 \\
Total/Average & 6 & 14 & -1 & -5 & -29500 & +14753 & +5899 & +8848 & -1946 & -13839 \\
\hline
\end{tabular}

"- " denotes a decrease compared to status quo scenario; "+" denotes an increase compared to status quo scenario. 
Hydrol. Earth Syst. Sci. Discuss., https://doi.org/10.5194/hess-2017-755

Manuscript under review for journal Hydrol. Earth Syst. Sci.

Discussion started: 10 January 2018
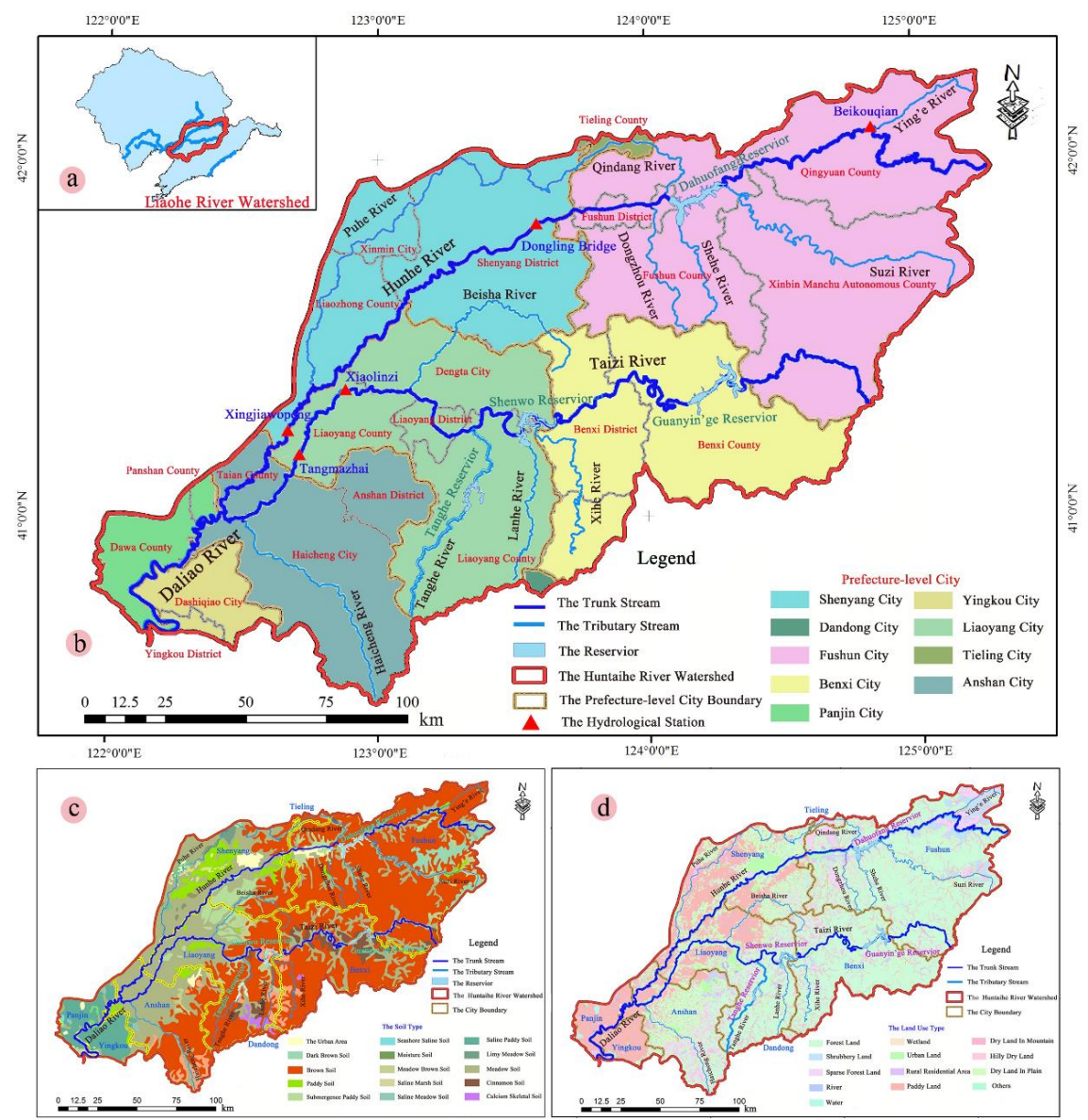

a. The location of the HTRW.

b. The geographical zoning of HTRW.

c. The land use type of HTRW.

d. The soil type of HTRW.

Figure 1. Basic information on the HTRW. The figure has been supplied by www.geodata.cn, which is a national science and technology basic conditions platform and an earth system science data sharing platform. The figure information is public. The Liaoning province Water Resources Administrative Bureau granted permission for the basic information in the HTRW. 
Hydrol. Earth Syst. Sci. Discuss., https://doi.org/10.5194/hess-2017-755

Manuscript under review for journal Hydrol. Earth Syst. Sci.

Discussion started: 10 January 2018

(c) Author(s) 2018. CC BY 4.0 License.

\begin{tabular}{|c|c|c|c|}
\hline $\begin{array}{c}\text { DEM (Digital } \\
\text { Elevation Model) }\end{array}$ & $1: 250000$ & $\begin{array}{l}\text { Elevation, overland and } \\
\text { channel slopes and lengths }\end{array}$ & $\begin{array}{l}\text { Institute of Geographical and Natural } \\
\text { Resources Research; } \\
\text { Chinese Academy of Sciences; Input } \\
\text { National Geomatics Center of China }\end{array}$ \\
\hline Land use & 1:100 000 & Land use classifications & $\begin{array}{l}\text { Institute of Geographical and Natural } \\
\text { Resources Research; } \\
\text { Chinese Academy of Sciences }\end{array}$ \\
\hline Soil properties & $1: 1000000$ & $\begin{array}{l}\text { Soil physical and chemical } \\
\text { properties }\end{array}$ & $\begin{array}{l}\text { Institute of Soil Science; } \\
\text { Chinese Academy of Sciences }\end{array}$ \\
\hline $\begin{array}{l}\text { Meteorological } \\
\text { data }\end{array}$ & 1 & $\begin{array}{c}\text { Precipitation, daily } \\
\text { maximum and minimum air } \\
\text { temperature, relative } \\
\text { humidity and solar radiation }\end{array}$ & $\begin{array}{l}\text { China Meteorological Administrat } \\
\text { Liaoning province bureau of } \\
\text { Meteorology }\end{array}$ \\
\hline $\begin{array}{l}\text { water quantity and } \\
\text { quality }\end{array}$ & I & 1 & $\begin{array}{l}\text { Local hydrographical station and } \\
\text { environmental monitoring station }\end{array}$ \\
\hline $\begin{array}{l}\text { Social economic } \\
\text { data }\end{array}$ & I & $\begin{array}{l}\text { Population, livestock } \\
\text { rearing, fertilizer } \\
\text { application }\end{array}$ & $\begin{array}{l}\text { Field investigation; } \\
\text { Statistics yearbook }\end{array}$ \\
\hline$\underbrace{\longleftarrow}$ Data type ${ }^{-}$ & -Data scale & -Data description & Data source \\
\hline
\end{tabular}

Figure 2. Data information in the HTRW. 
Hydrol. Earth Syst. Sci. Discuss., https://doi.org/10.5194/hess-2017-755

Manuscript under review for journal Hydrol. Earth Syst. Sci.

Discussion started: 10 January 2018

(c) Author(s) 2018. CC BY 4.0 License.

Hydrology and

Discussions

(c) (i)

\begin{tabular}{|c|c|c|c|c|c|}
\hline CN2 & Initial SCS Runoff curve number for moisture condition & $25-92$ & - & Reduce by 5 & Soil water content \\
\hline ESCO & Soil evaporation compensation factor & $0.01-1$ & 0.95 & 0.19 & Surface runoff simulation \\
\hline GWQMN & $\begin{array}{l}\text { Threshold depth of water in shallow aquifer required for the return } \\
\text { flow to occur }\end{array}$ & $0-5000$ & 0 & 1200 & $\begin{array}{l}\text { Surface runoff simulation } \\
\text { Sus }\end{array}$ \\
\hline $\begin{array}{l}\text { SPEXP } \\
\text { PRF }\end{array}$ & $\begin{array}{l}\text { Exponent parameter for calculating sediment entrained in channel } \\
\text { sediment routing }\end{array}$ & $1-1.5$ & 1 & 1.45 & Sediment assessment \\
\hline \multirow{2}{*}{$\begin{array}{l}\text { SURLAG } \\
\text { ADJ_PKR }\end{array}$} & Peak rate adjustment factor for sediment routing in the main channel & $0-2$ & 1 & 1.97 & Surface runoff simulation \\
\hline & Surface runoff lag time & $1-24$ & 4 & 4 & l \\
\hline PPERCO & Peak rate adjustment factor for sediment routing in sub basins & $0.5-2$ & 0.5 & 2 & Phosphorus assessment \\
\hline PHOSKD & P percolation coefficient & $10-17.5$ & 10 & 17.5 & Phosphorus assessment \\
\hline \multirow{2}{*}{ P_UPDIS } & P soil partitioning coefficient & $100-200$ & 175 & 175 & \multirow[t]{2}{*}{ (1) } \\
\hline & $\mathrm{P}$ uptake distribution factor & $0-100$ & 20 & 80 & \\
\hline PSP & Phosphorus sorption coefficient & $0.01-0.7$ & 0.4 & 0.6 & / \\
\hline SOL_LABP & Initial soluble $\mathrm{P}$ concentration in surface soil layer $(\mathrm{mg} / \mathrm{kg})$ & $0-100$ & 0 & 12 & Phosphorus assessment \\
\hline NPERCO & $\mathrm{N}$ percolation coefficient & $0-1$ & 0.2 & 0.8 & Nitrogen assessment \\
\hline $\mathrm{SOL}_{-} \mathrm{NO}_{3}$ & Initial $\mathrm{NO}_{3}$ concentration in the soil $(\mathrm{mg} / \mathrm{kg})$ & $0-100$ & 0 & 20 & Nitrogen assessment \\
\hline
\end{tabular}

Figure 3. Parameters calibration of SWAT model in the HTRW. 
Hydrol. Earth Syst. Sci. Discuss., https://doi.org/10.5194/hess-2017-755

Manuscript under review for journal Hydrol. Earth Syst. Sci.

Discussion started: 10 January 2018

(c) Author(s) 2018. CC BY 4.0 License.
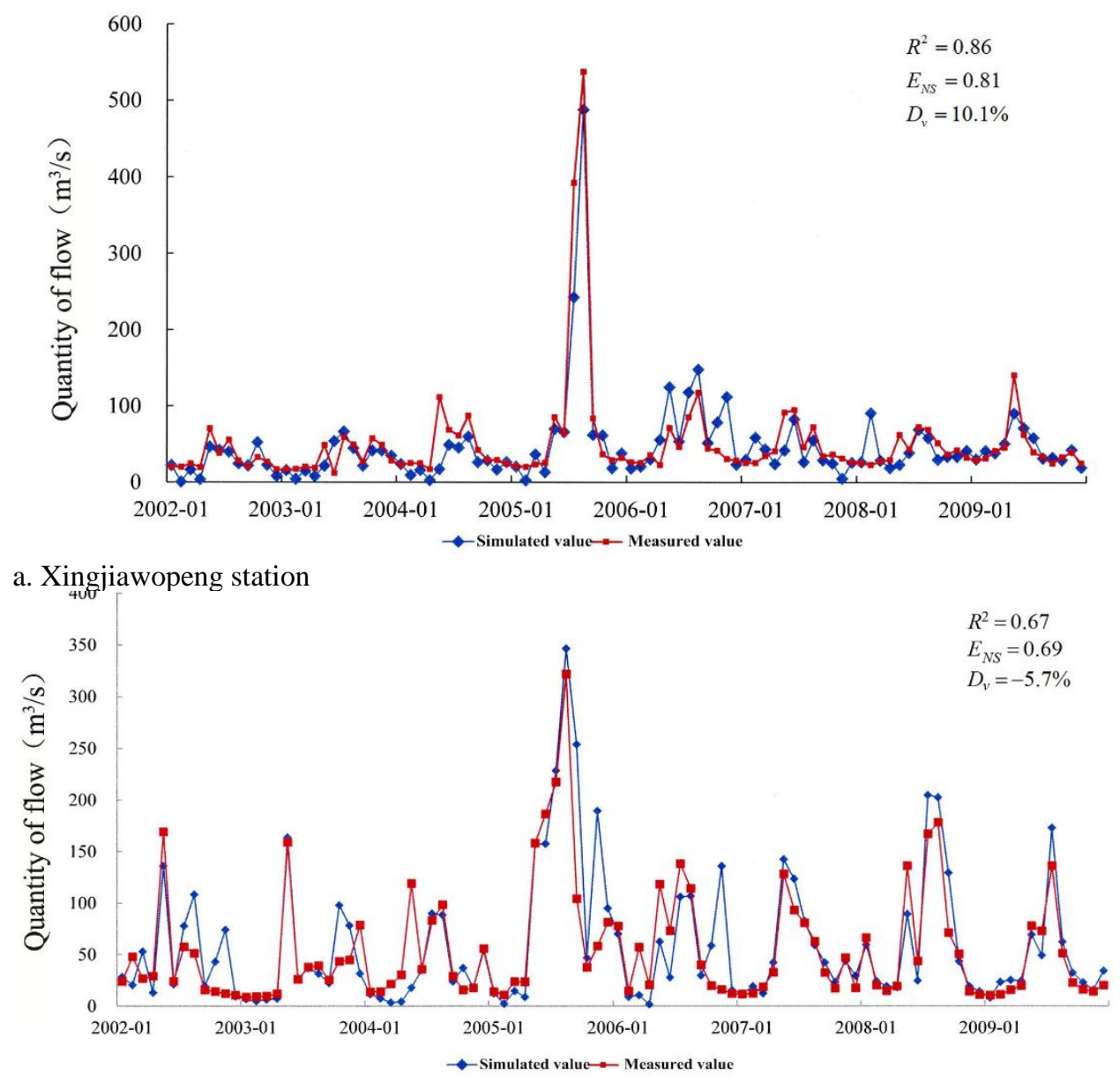

b. Tangmazhai station

Figure 4. The stream flow validation result of typical monitoring station. 
Hydrol. Earth Syst. Sci. Discuss., https://doi.org/10.5194/hess-2017-755

Manuscript under review for journal Hydrol. Earth Syst. Sci.

Discussion started: 10 January 2018

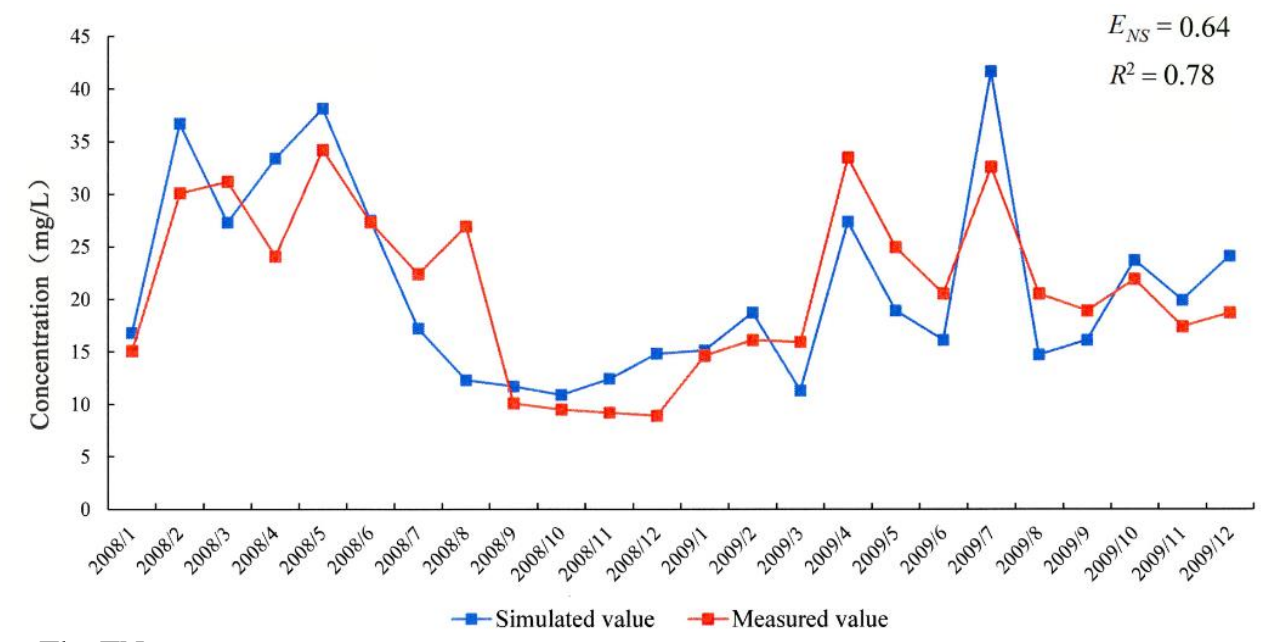

a. The TN

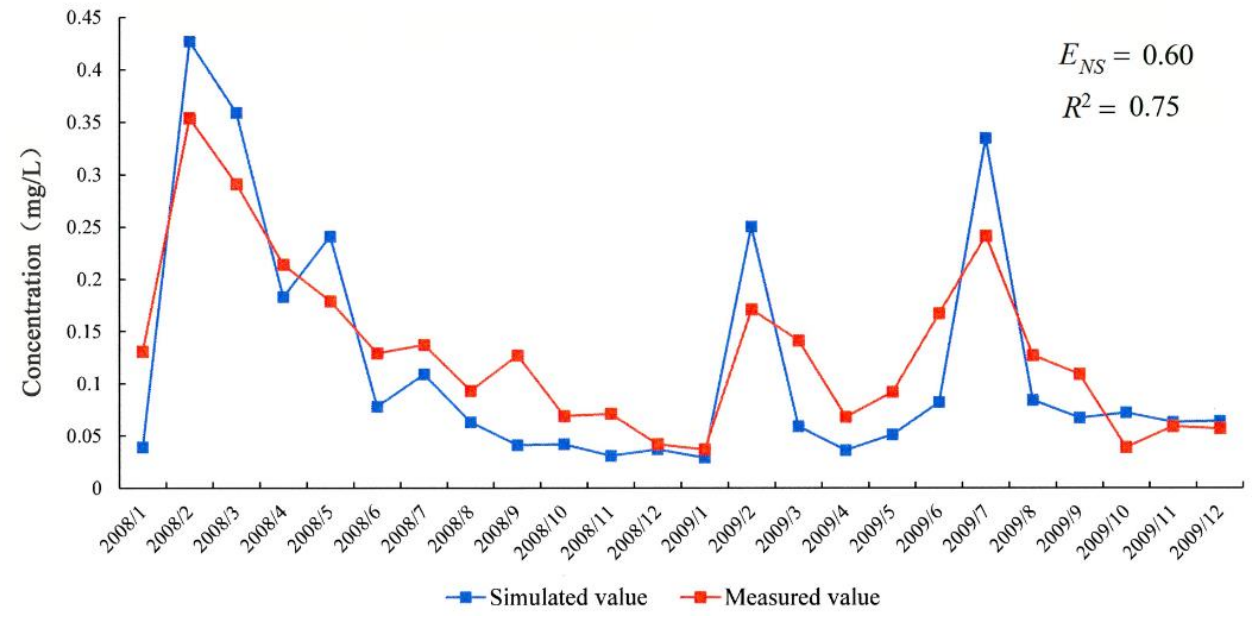

b. The TP

Figure 5. The nutrients validation in Beikouqian station. 
Hydrol. Earth Syst. Sci. Discuss., https://doi.org/10.5194/hess-2017-755

Manuscript under review for journal Hydrol. Earth Syst. Sci.

Discussion started: 10 January 2018

Hydrology and

Earth System

Sciences

(c) Author(s) 2018. CC BY 4.0 License.

Discussions

(c) (1)

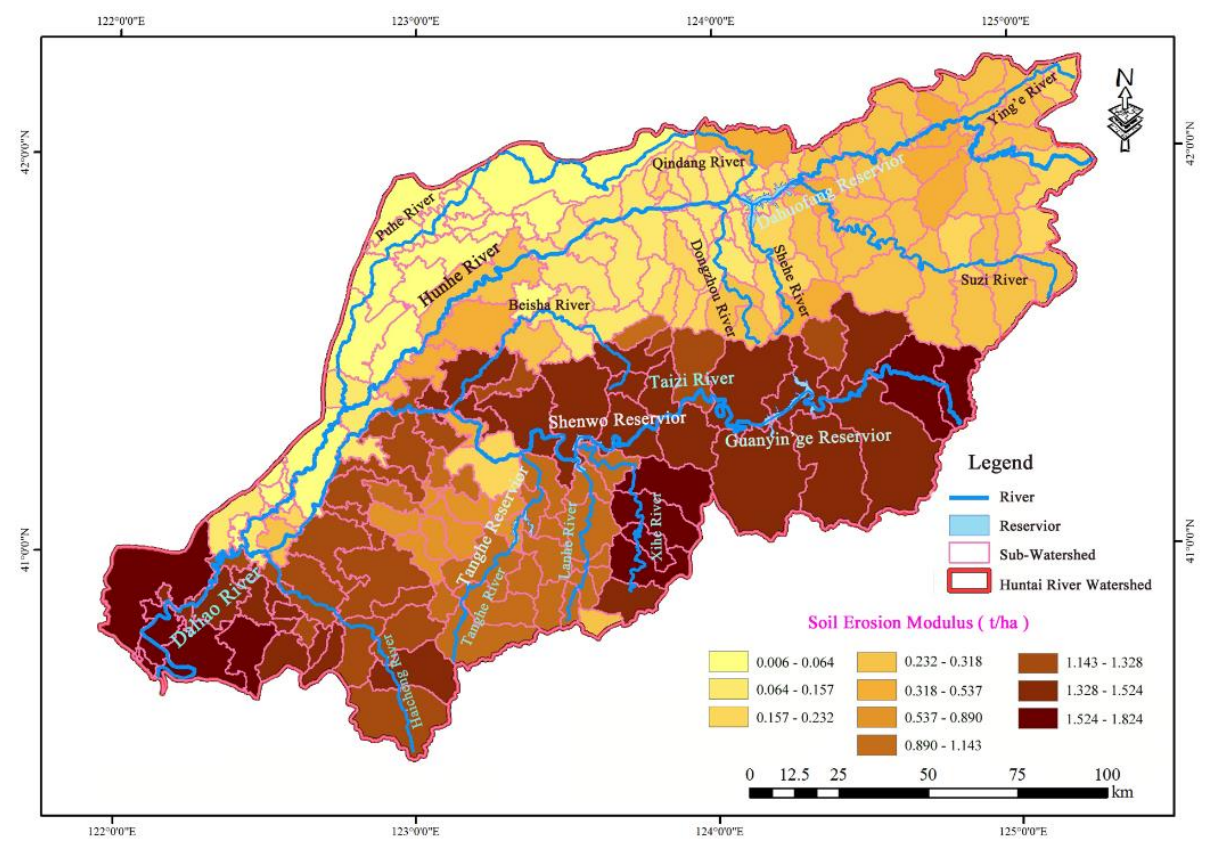

a. The sediment.

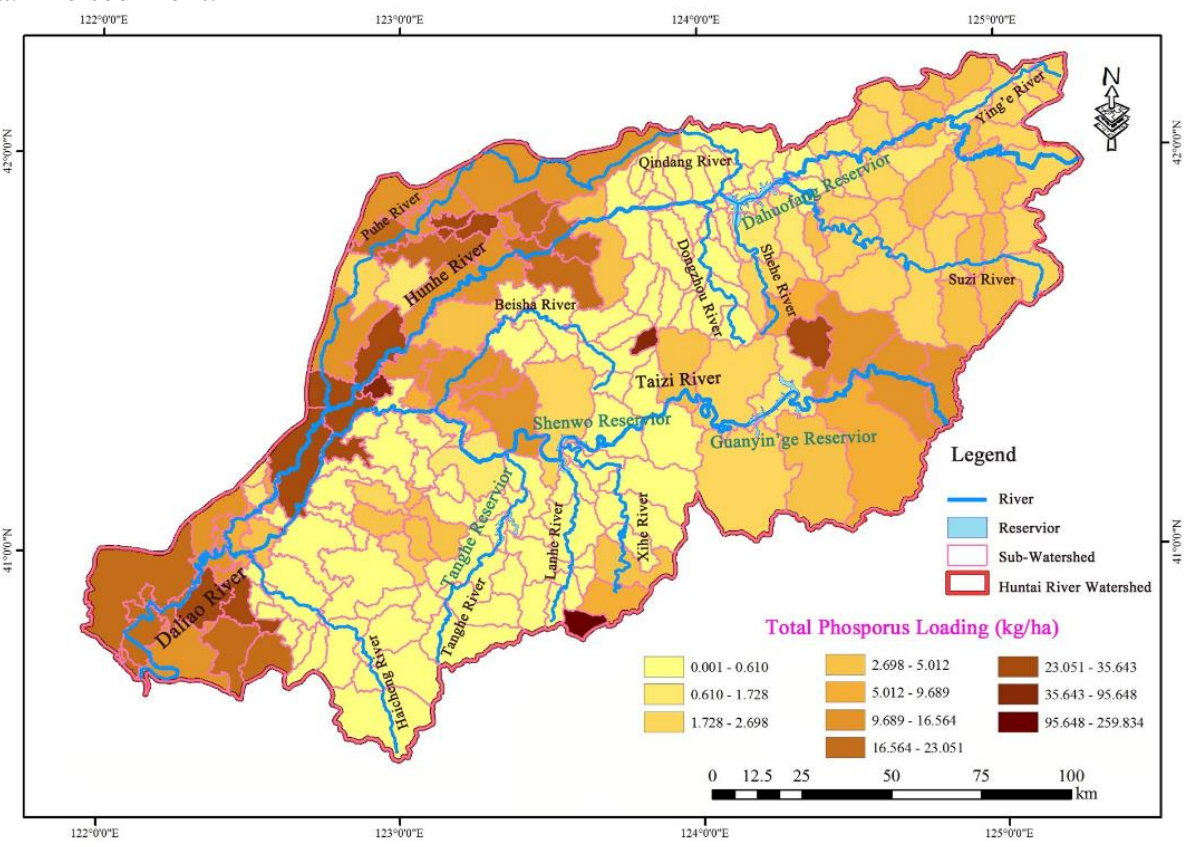

b. The TP. 
Hydrol. Earth Syst. Sci. Discuss., https://doi.org/10.5194/hess-2017-755

Manuscript under review for journal Hydrol. Earth Syst. Sci.

Discussion started: 10 January 2018

(c) Author(s) 2018. CC BY 4.0 License.

(c) (i)

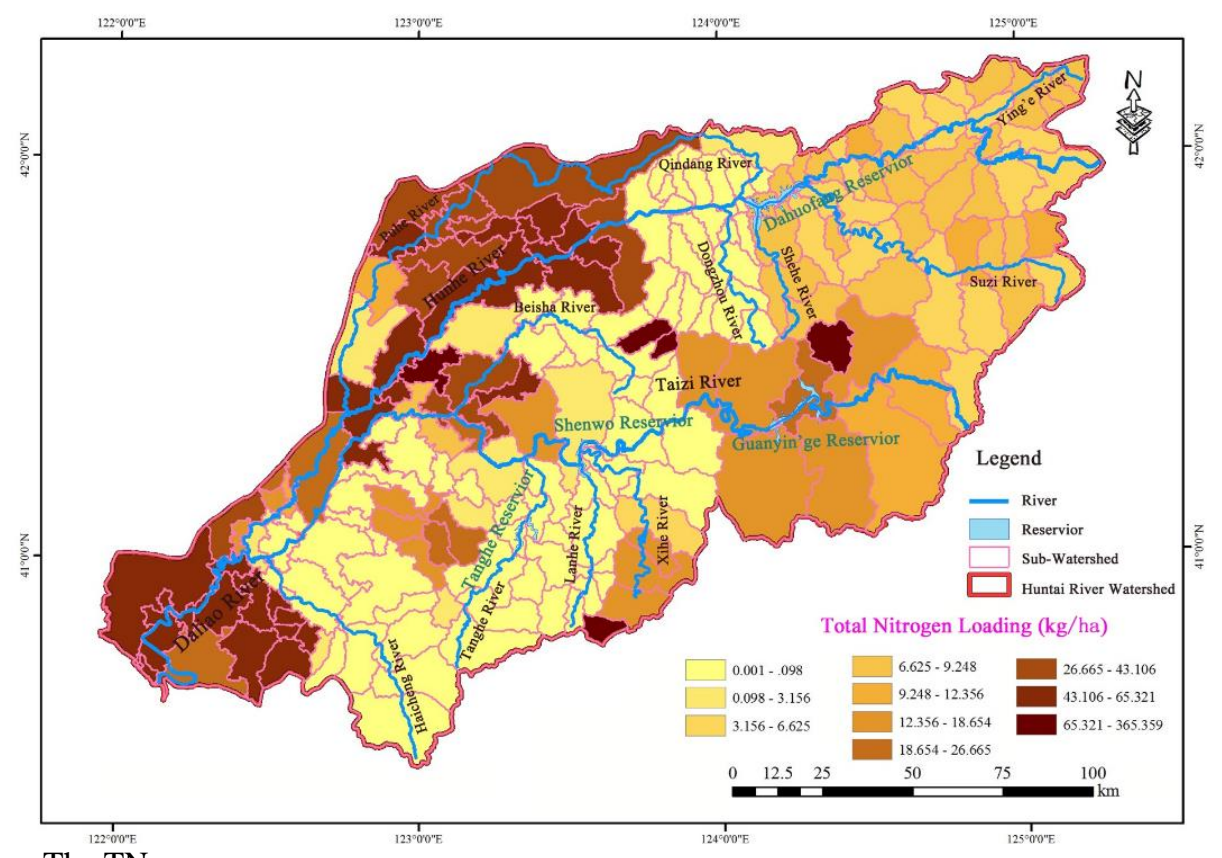

c. The TN.

Figure 6. NPS pollution loading distributions of HTRW under status quo scenario. 